\title{
FACTORS OF CUSTOMER LOYALTY IN PHARMACY RETAIL: A CASE FROM BULGARIA
}

\author{
Valeriya Nikolova $^{1}$, Reneta Dyankova ${ }^{2}$, Hristina Petkova ${ }^{3}$ \\ ${ }^{1}$ Department of Economics and Healthcare Management, Faculty of Public Health, \\ Medical University of Varna \\ ${ }^{2}$ Master's Program in Healthcare Management, Faculty of Public Health, \\ Medical University of Varna \\ ${ }^{3}$ Master's Program in Pharmaceutical Management, Faculty of Public Health, \\ Medical University of Varna
}

\begin{abstract}
INTRODUCTION: Pharmacy retail in Bulgaria has been a growing market in last few years. There are more pharmacies in big cities than in smaller towns and villages. There is a large competition between pharmacies in big cities and they offer many services to retain their customers.
\end{abstract}

MATERIALS AND METHODS: An empirical sociological research was conducted among 433 adult citizens in Varna, in February 2017, using a structured questionnaire. It was developed by the authors to explore the customers' preferences and attitudes when choosing a pharmacy.

RESULTS: The respondents were predominantly women (65\%). They were divided into several age groups. According to the social status, working individuals prevailed (44\%), followed by students (32\%), entrepreneurs $(10 \%)$ and retired people (10\%). These demographic characteristics have key role in the determination of the factors of customer loyalty.

CONCLUSION: According to this survey, customer loyalty to a particular pharmacy depends on the range of products it offers, low prices and competent and friendly personnel. The leading factors for customer loyalty are various and pharmacies must meet their expectations and challenges in this competitive market.

Keywords: pharmacy, loyalty, satisfaction, customers

\section{INTRODUCTION}

At the service level, loyalty is defined as "the degree to which a customer exhibits repeat purchasing behavior from a service provider, possesses a positive attitudinal disposition toward the provider, and

\footnotetext{
Address for correspondence:

Valeriya Nikolova

Faculty of Public Health

Medical University of Varna,

55 Marin Drinov St

9002 Varna, Bulgaria

e-mail:valeriya.v.nikolova@gmail.com
}

Received: October 31, 2017

Accepted: November 8, 2017 considers using only this provider when a need for this service arises" (1). According to the researchers, loyalty is a combination of attitudinal (loyalty intentions or cognitive/attitudinal loyalty) and behavioral factors (behavioral loyalty) (2). Since the public has traditionally recognized community pharmacies mainly as medicine traders, this sector has not considered loyalty as a key concept. Consequently, several studies have investigated this concept within the pharmaceutical retail sector (3). The investigation on community pharmacy loyalty shows that pharmacists' technical skills are not key in determining patients' loyalty (4). Several studies have discussed the relationship between consumer satisfaction and the loyalty toward a service provider or a 
retailer and have argued that customer satisfaction usually leads to loyalty and trust (3,5-9). Another group of research papers showed that offering value-added pharmacy services is another key factor for attracting patients and increasing the confidence in pharmacists as healthcare professionals (10-12).

The pharmaceutical retail market in Bulgaria is characterized by a high concentration of community pharmacies in the big cities. Although this is a growing market, the number of pharmacies exceeds this expand and leads to severe competition between them. Therefore, the ability to gain customer loyalty could increase the pharmacy competitiveness. Varna, the third largest city in Bulgaria, has about 395 000 inhabitants (13). There are 189 registered pharmacies, according to the Bulgarian Drug Agency and there is a serious competition (14). Most of them are situated near hospitals, medical centers and big supermarkets or malls. The great variety of choice, the various offers in each pharmacy make customers more willing and demanding.

\section{AIM}

The aim of this study is to investigate the main and supplementary factors of customer loyalty in the pharmaceutical retail market.

\section{MATERIALS AND METHODS}

An empirical sociological research was conducted among 433 citizens living in Varna, in February 2017, using a structured questionnaire. The survey included 433 respondents of which - men (35\%) and women (65\%). The questionnaire included questions about the leading factors for customer loyalty, customer preferences and attitudes when choosing a pharmacy.

\section{RESULTS}

The respondents were predominantly women (65\%). They were divided into several age groups: 18 25 (35\%), 26-35 (15\%), 36-45 (20\%), 46-60 (17\%), and over 60 years of age (10\%). According to the social status, working individuals prevailed (44\%), followed by students $(32 \%)$, entrepreneurs $(10 \%)$ and retired people (10\%). Most of the respondents (34\%) had monthly income between BGN 501 and BGN 1000. These demographic characteristics had a key role in determining the factors of customer loyalty. They are important specifics for local pharmacy retail and for customer satisfaction.

\section{DISCUSSION}

According to our survey, the vast product portfolio, competent and polite service and low prices can be identified as key factors or drivers of loyalty (Fig. 1). The range of product portfolio is the most important factor for men ( $73 \%$ of male respondents) and women (68\% of female respondents) mostly state the competent service. The low prices attract mainly pensioners and people with lower income.

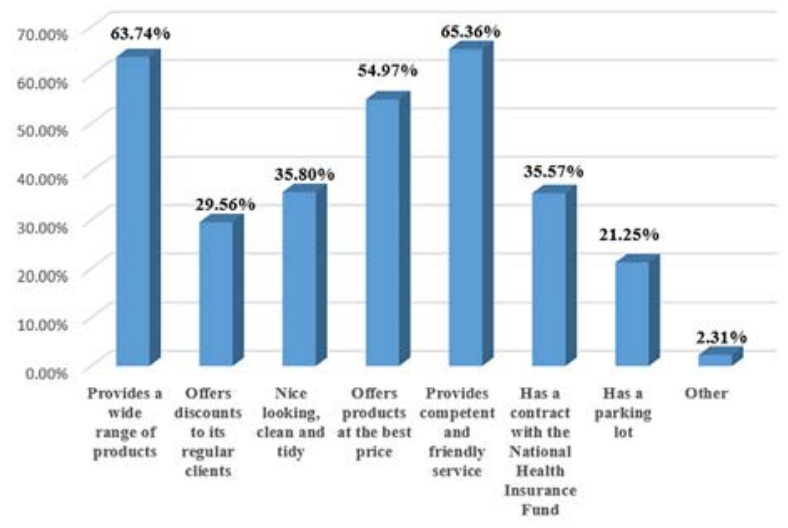

Fig. 1. Key factors of customer loyalty

The leading factor of customer loyalty is a wide range of products. In Bulgaria there are nearly 300 registered pharmaceutical companies with a vast portfolio of products (15). In the last five years, the most popular products in Bulgaria are over-thecounter (OTC) products. These products have an increasing popularity nowadays. This is due to the information customers receive from the Internet and their knowledge about the ingredients in drugs, OTC products, medical cosmetics, etc. All this makes them loyal to a specific brand. It is a big challenge for pharmacies to have many products available to satisfy customers' preferences. Pharmacists must have a good communication with physicians in the region because respondents indicate that they buy medicaments prescribed by a physician (73\%) and not many agree for it to be changed (20\%). These results show the importance of maintaining a wide assortment, especially for frequently prescribed drugs. Gebauer argues that pharmacies could use their assortment to differentiate themselves from other retailers and classifies pharmacies according to their different of- 
fers. Previous studies find that in grocery stores, consumer expenditures correspond more to the varying assortment levels than to the prices (16-17). The assortment is also considered a key attribute of the store image and a predictor of consumers' choice of shopping destinations, which is the main reason why a wide range of products is a leading factor of loyalty (18-20). The second one is increasing the information awareness of patients.

The results show that a competent and friendly personnel is another key factor of customers' loyalty. Pharmacy communication is a primary element in building and managing its relationship with its patients (3). In healthcare studies, communication is considered to be the information exchange between patients and staff about medical conditions, treatment, and possible results. The results indicate that the providers' skills, knowledge, and their respectful communication with the patients are the most important factors (20). The customers expect a competitive service, especially when they buy drugs without prescription, OTC products, etc. Physicians' and pharmacists' recommendation is of major significance in this case. That shows the importance of the human factor. The well-trained and motivated personnel plays a key role in the choice of a pharmacy. It is the leading reason for urban areas, where there is a severe competition. In Varna, there are districts where pharmacies are near one another and keeping the regular customers is of utmost importance. The most frequent questions asked by the customers are about genetically modified organism (GMO) or sugar content in the drugs, the kind of coloring agent, the way of administering, etc. This brief exchange increases customer satisfaction and loyalty as a concept is influenced by satisfaction (21). There are studies, which show the central role of trust in the healthcare context, especially patients' trust in their physicians and other healthcare service providers (22).

Surprisingly, the low price of the drugs is the third key factor of customer loyalty, despite the fact that Bulgaria is a country with low income, demographic crisis and aging population. The low prices and promotions are leading factors for respondents at an age over 60 (72\%). In big cities, competition is more severe than in small towns and villages. According to the database, four local and four national pharmacy chains operate in Varna. They of- fer regular promotions. They can afford to sell at low prices in contrast to small pharmacies. Some of them have their own monthly bulletin, where they publish health advice, interviews with health specialists and product promotions.

As supplementary factors, which affect decisions, we can determine additional services, such as measuring of blood pressure, consultations with a dermatologist and extemporaneous preparation of medicines (Fig. 2). Additional services are preferred by $57 \%$ of men and $64 \%$ of young respondents, whereas $67 \%$ of the women and $72 \%$ of the respondents with high income prefer consultations with a dermatologist. Pediatricians and dermatologists can prescribe extemporaneous drugs. In Varna, very few pharmacies prepare pharmaceutical and cosmetic products. In last two years, most of pharmacies in Varna have offered free blood pressure for their clients. This is a successful strategy for customer satisfaction. There is no pharmacy in Varna where customers could have a consultation with dermatologist or another specialist. This option is more popular in optics where patients are consulted by ophthalmologist.

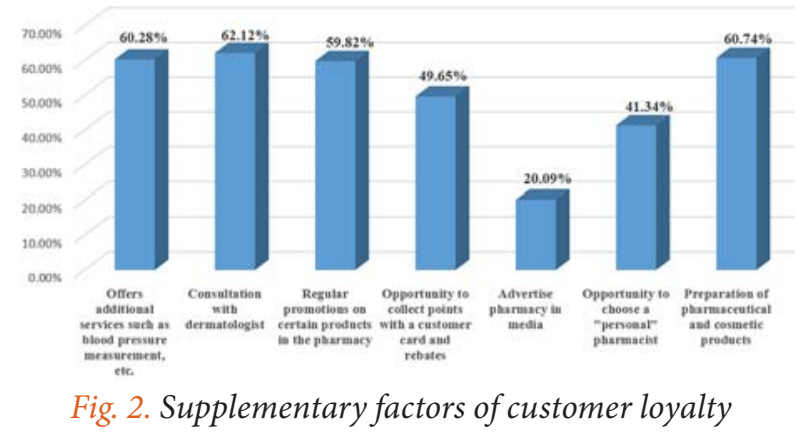

\section{CONCLUSION}

According to this survey, customer loyalty to a particular pharmacy depends on the wide range it offers, low prices and competent and friendly personnel. Results show that the supply of additional services in the pharmacy is also an important factor for increasing customer loyalty. In view of the increasing competition in this sector, the availability of a variety of goods, organizing regular promotions, the introduction of attractive and additional services are very important for the success of the pharmacy.

To gain loyal customers, a pharmacy should apply competitive strategies aimed at creating the right 
Valeriya Nikolova, Reneta Dyankova, Hristina Petkova

mix of service characteristics, which clients value most, rather than to achieve a single competitive advantage. To be successful and to create a permanent customer network, the pharmacy has to be flexible and meet the customers' expectations.

\section{Conflict of Interest}

The authors declare no conflict of interest

\section{REFERENCES}

1. Edvardsson B, Brown SW, Johnston R, Scheuing E, editors. Advancing Service Quality: A Global Perspective. New York: ISQA1; 1996. 171-8.

2. Dick A, Basu K. Customer loyalty: towards an integrated framework. J Acad Market. 1994; 2:99-113.

3. Castaldo S, Grosso M, Mallarini E, Rindome M. The missing path to gain customers loyalty in pharmacy retail: The role of the store in developing satisfaction and trust. Res Social Adm Pharm. 2016;12(5):699-712. doi: 10.1016/j. sapharm.2015.10.001

4. Antunes LP, Gomes JJ, Cavaco AM. How pharmacist-patient communication determines pharmacy loyalty? Modeling relevant factors. Res Social Adm Pharm. 2015; 11:560-70. doi: 10.1016/j. sapharm.2014.11.003

5. Zeithaml VA, Berry L, Parasuraman A. Behavioral consequences of service quality. J Market. 1996; 60(2):31-46.

6. Anderson EW, Sullivan MW. The antecedents and consequences of customer satisfaction. Market Sci. 1993; 12(2):125-43. doi: 10.1287/mksc.12.2.125

7. Wang CY. Service quality, perceived value, corporate image, and customer loyalty in the context of varying levels of switching costs. Psychol Market. 2010;27(3):252-62. doi: 10.1002/mar.20330

8. Olsen SO. Repurchase loyalty: the role of involvement and satisfaction. Psychol Market. 2007; 24(4):315-41. doi: 10.1002/mar.20163

9. Ganesan S. Determinants of long-term orientation in buyer-seller relationships. J Market. 1994: 58(2):1-19. doi: 10.2307/1252265

10. Grigorov E, Kostov E, Lebanova H, Getov I. Model approach for planning of value-added pharmacy services in community pharmacy. Health policy and management. 2013; 13:48-52.

11. Grigorov E, Kostov E, Lebanova H, Getov I. Characteristics of value-added pharmacy services in community pharmacy. Social medicine. 2012; 20:38-9.

12. Grigorov E, Dolmayan G, Getov I. Test-study willingness to pay for added-value services in the pharmacy. Health policy and management. 2011; 11:29-33.

13. National Statistical Institute. Bulgaria: Population by towns and sex; [updated 2016 Dec 31; cited 2017 May 12]. Available from : http://www.nsi.bg/bg/ content/2981.html

14. Bulgarian Drug Agency. Bulgaria: Register of pharmacies; [updated 2017 Apr 24; cited 2017 May 12]. Available from : http://www.bda.bg/index.php

15. Bulgarian Drug Agency. Register of the wholesalers with pharmaceutical trading license. Sofia, 2015. [updated 2017 Apr 12; cited 2017 May 12]. Available from : http://www.bda.bg/index.php

16. Gebauer H. Robust management policies for positioning pharmacies as healthcare service providers. Eur Manage J. 2008; 26(3):175-87. doi: 10.1016/j. emj.2008.01.003

17. Fox EJ, Montgomery AL, Lodish LM. Consumer shopping and spending across retail formats. J Bus. 2004; 77(2):25-60.

18. Mazursky D, Jacoby J. Exploring the development of store images. J Retail. 1986; 62(2):145-65.

19. Oppewal H, Louviere JJ, Timmermans H. Modelling the effects of shopping centre size and store variety on consumer choice behavior. Environ Plan A. 1997; 29(6):1073-90.

20. Hall MA, Camacho F, Dugan E, Balkrishnan $\mathrm{R}$. Trust in the medical profession: conceptual and measurement issues. Health Serv Res. 2002; 37(5):1419-39.

21. Antunes L, Gomes J, Cavaco A. How pharmacist-patient communication determines pharmacy loyalty? Modeling relevant factors. Res Social Adm Pharm. 2015;11(4):560-70. doi: 10.1016/j. sapharm.2014.11.003

22. Pearson SD, Raeke LH. Patients' trust in physicians: many theories, few measures, and little data. J Gen Intern Med. 2000; 15(7):509-513. 